\title{
Pseudomonas mosselii
}

National Cancer Institute

\section{Source}

National Cancer Institute. Pseudomonas mosselii. NCI Thesaurus. Code C86703.

A species of aerobic, Gram negative, rod shaped bacteria in the phylum Proteobacteria.

This species is motile, non spore forming, negative for elastase, coagulase,

chondroitinase, hyaluronidase and tetrathionate reductase and positive for arg inine

dihydrolase, catalase and cytochrome. P. mosselii is not a known pathogen. 